Article

\title{
Structural changes of Rh-Mn nanoparticles inside carbon nanotubes studied by X-ray absorption spectroscopy
}

\author{
Hongliang Bao, Xueping Sun, Zheng Jiang, Yuying Huang\#, Jianqiang Wang* \\ Shanghai Synchrotron Radiation Facility, and Key Laboratory of Interfacial Physics and Technology, Shanghai Institute of Applied Physics, \\ Chinese Academy of Sciences, Shanghai 201204, China
}

A R T I C L E I N F O

Article history:

Received 20 January 2014

Accepted 12 March 2014

Published 20 August 2014

\section{Keywords:}

Rhodium

Manganese

Nanoparticle

X-ray absorption near-edge

spectroscopy

Extended X-ray absorption fine

structure spectroscopy

\begin{abstract}
A B S T R A C T
Supported Rh-based catalysts such as Rh-Mn nanoparticles (NPs) have potential use in the synthesis of ethanol from syngas. The structure of Rh-Mn NPs in multi-walled carbon nanotubes under different atmospheres and temperatures was studied by X-ray absorption spectroscopy (XAS). TEM images showed that the NPs dispersed in the carbon nanotubes had a uniform size of $2 \mathrm{~nm}$. XAS data revealed that the Rh-Mn NPs before reduction were composed of $\mathrm{Rh}_{2} \mathrm{O}_{3}$ clusters and mixed Mn oxide species. After reduction in a $10 \% \mathrm{H}_{2}-90 \% \mathrm{He}$ atmosphere, the mixed Mn oxides were converted into nearly pure $\mathrm{MnO}$. In contrast, the $\mathrm{Rh}_{2} \mathrm{O}_{3}$ clusters were easily decomposed to metallic $\mathrm{Rh}$ clusters even under a He atmosphere at $250^{\circ} \mathrm{C}$. The Rh clusters remained in the metal state under the next reduction atmosphere, but their dispersion in the Rh-Mn NPs increased with increasing temperature. No significant Mn-Rh or Mn-O-Rh interaction in the reduced NPs was observed in the extended X-ray absorption fine structure analysis. The results showed that there was no interaction between the $\mathrm{MnO}$ particles and Rhclusters and the role of the Mn promoter was mainly to improve Rh dispersion.
\end{abstract}

(C) 2014, Dalian Institute of Chemical Physics, Chinese Academy of Sciences. Published by Elsevier B.V. All rights reserved.

\section{Introduction}

The synthesis of ethanol from syngas has received attention in recent years for its use as an alternative fuel to reduce the global dependence on petroleum [1-4]. The conversion of biomass to syngas by a catalytic process provides a promising alternate route to synthesize ethanol on a large scale [5]. Although a large amount of research on this synthesis route has been done, there is as yet no commercial process due to the existing challenges [6]. A growing consensus is that a supported $\mathrm{Rh}$ catalyst could be the most suitable catalyst for this catalytic conversion route because supported $\mathrm{Rh}$ particles can simultaneously adsorb $\mathrm{CO}$ in both molecular and dissociated states, but the catalytic performance up to now is poor $[7,8]$. In order to enhance the catalytic activity of Rh, numerous methods have been tried, such as using a suitable support and adding promoters [9-18]. Recently, confining Rh or Rh-based nanoparticles in a limited space, such as in a zeolitic material or carbon nanotubes (CNTs), was shown to be an effective approach to improve the yield and selectivity for ethanol production from syngas [19-25].

$\mathrm{Mn}$ is a common promoter widely added to $\mathrm{Rh}$ to form supported Rh-Mn catalysts. A substantial amount of work has been carried out to investigate the promoting effects of $\mathrm{Mn}$ in the supported Rh-Mn catalysts [26-28]. However, there is still uncertainty about the state of $\mathrm{Mn}$ and the interaction between $\mathrm{Mn}$

\footnotetext{
*Corresponding author. Tel/Fax: +86-21-33933212; E-mail: wangjianqiang@sinap.ac.cn

\# Corresponding author. Tel/Fax: +86-21-33933212; E-mail: huangyuying@sinap.ac.cn

This work was supported by the National Natural Science Foundation of China (91127001, 21001112, and 11079005).

DOI: 10.1016/S1872-2067(14)60081-4 | http://www.sciencedirect.com/science/journal/18722067 | Chin. J. Catal., Vol. 35, No. 8, August 2014
} 
and $\mathrm{Rh}$ in Rh-Mn catalysts. Wilson et al. [29] showed that Mn species exist as $\mathrm{Mn}^{2+}$ together with $\mathrm{Rh}^{+}$on a silica support. It has been found that Mn oxides cannot be completely reduced to metallic Mn in Rh-Mn catalysts [30]. In contrast, Luo et al. [31] found that $\mathrm{Rh}$ promoted the reduction of Mn oxides. In addition, it was proposed that the promoter Mn exists with $\mathrm{Rh}$ in a binary alloy [27]. Therefore, the determination of the chemical state of the Mn promoter and clarification of the interaction between Mn and Rh are critical for understanding the promoting effects of $\mathrm{Mn}$ in supported Rh-Mn catalysts. X-ray absorption spectroscopy (XAS), including X-ray absorption near-edge spectroscopy (XANES) and extended X-ray absorption fine structure spectroscopy (EXAFS), is a useful tool for this research. They can provide information about the electronic structure of the absorbing atoms and the local geometric structure surrounding the central absorbing atoms [32]. Besides, the XAS technique also can selectively detect an element and can be used for in situ measurement [33], so it is highly suitable for the study of the structure of Rh-Mn catalysts under a reduction atmosphere.

In this work, we used a supported Rh-Mn catalyst whose Rh-Mn nanoparticles (NPs) were inside multi-walled CNTs (MWCNTs) with nominal loading (mass fraction) of 5\% Rh and 5\% Mn, denoted as Rh-Mn@CNT, and investigated the structure of the Rh-Mn NPs by XAS analysis. Structural information of the Rh-Mn@CNT catalyst under a reduction atmosphere $\left(10 \% \mathrm{H}_{2}\right.$ or $10 \% \mathrm{CO}$ balanced with $\left.\mathrm{He}\right)$, such as the chemical states of $\mathrm{Mn}$ and $\mathrm{Rh}$ and the interaction between Mn and Rh, was extracted by analyzing the $\mathrm{Mn}$ and $\mathrm{Rh}$ K-edge XAS data. The results provide information for understanding the structure of Rh-Mn catalysts under reaction conditions and the promoting effects of Mn during ethanol synthesis from syngas over the supported Rh-Mn catalysts.

\section{Experimental}

\subsection{Preparation of catalyst}

Rh-Mn NPs in CNT channels as a catalyst for the production of ethanol from syngas were synthesized by a wet chemistry method described in a previous paper [19]. MWCNTs with 4-8 $\mathrm{nm}$ inner diameter and 250-500 nm length were used as a vessel to hold the Rh-Mn NPs.

\subsection{TEM characterization}

Transmission electron microscope (TEM) images were obtained using a FEI Tecnai G2 F20 S-TWIN TEM operated at an accelerating voltage of $200 \mathrm{kV}$. TEM grids were prepared by loading the sample dispersed ultrasonically in ethanol onto a copper grid.

\subsection{XAS measurement and data analysis}

The XAS data were collected on beam line BL14W1 at the Shanghai Synchrotron Radiation Facility. The electron storage ring was operated at $3.5 \mathrm{GeV}$. A double $\mathrm{Si}(111)$ or $\mathrm{Si}(311)$ crys- tal monochromator was employed for energy selection. Mn K-edge XAS data of the catalyst were acquired in transmission mode while the Rh K-edge XAS data were acquired in fluorescence mode by using a 32-element Ge solid state detector. XAS data of $\mathrm{Rh}$ foil, $\mathrm{Rh}_{2} \mathrm{O}_{3}, \mathrm{Mn}$ foil, $\mathrm{MnO}$, and $\mathrm{Mn}_{2} \mathrm{O}_{3}$ were also measured under a similar condition for reference. An in situ cell was employed for collecting in situ XAS data under ordinary pressure in different atmospheres at different temperatures. The in situ cell was modified from a commercial Linkam T95 device (purchased from Linkam Scientific Instruments Ltd). An appropriate amount of catalyst and LiF powder was uniformly mixed, and then the mixture was crushed and formed into a pellet by using a rubber sheeter. The sample was processed by atmospheres in the order of $\mathrm{He}, 10 \% \mathrm{H}_{2}-90 \% \mathrm{He}$, and $10 \% \mathrm{CO}-$ $90 \%$ He. Under each atmosphere, the temperature was increased from room temperature (RT) to $300{ }^{\circ} \mathrm{C}$ followed by annealing from $250{ }^{\circ} \mathrm{C}$ to RT before changing the atmosphere. The flow rate of gas was $80 \mathrm{~mL} / \mathrm{min}$. The rate of the heating was $5^{\circ} \mathrm{C} / \mathrm{min}$ and the time of heating at the final temperature was $1 \mathrm{~h}$ prior to the XAS scan. XAS data analysis was carried out using the Ifeffit software package [34]. The normalized EXAFS function, $\chi(E)$, was transformed from energy space to $k$-space, $\chi(k)$, where $k$ is the photoelectron wave vector. The $\chi(k)$ data were multiplied by $k^{2}$ to compensate for the damping of EXAFS oscillations in the high $k$-region. The backscattering amplitude and phase shift were obtained from theoretical calculation using the FEFF code (version 6.0) [32]. $S_{0}^{2}$ values of 0.65 and 0.85 were obtained from fitting to $\mathrm{MnO}$ and $\mathrm{Rh}$ standard samples. From the analysis, structural parameters, such as the coordination number $(N)$, bond distance $(R)$, Debye-Waller factor $\left(\sigma^{2}\right)$, and inner potential shift $\left(\Delta E_{0}\right)$, could be calculated.

\section{Results and discussion}

The detailed TEM characterization of the Rh-Mn@CNT catalyst was reported in a previous paper [19]. Here, the TEM technique was used to confirm the presence of Rh-Mn NPs inside the CNTs. The TEM image of the Rh-Mn@CNT catalyst is shown in Fig. 1, which showed that the Rh-Mn NPs were well dispersed inside the CNT channels with a uniform size of approximately $2 \mathrm{~nm}$.

The catalytic reactions are normally performed at an industrial temperature and in an industrial atmosphere. In order to

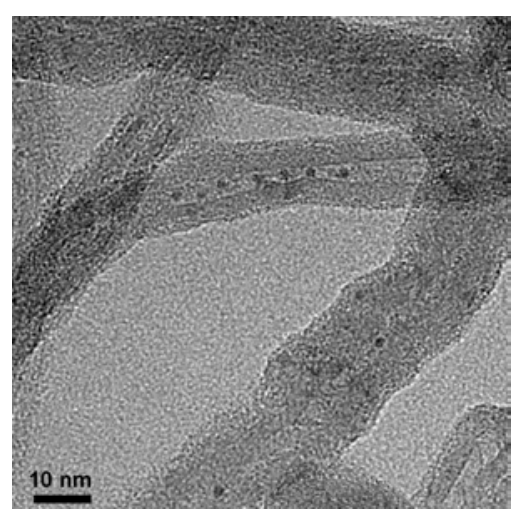

Fig. 1. TEM image of the Rh-Mn@CNT catalyst. 
investigate the actual working chemical state and local geometric structure of both $\mathrm{Mn}$ and $\mathrm{Rh}$, we performed in situ XAS measurements under different atmospheres at different temperatures. Prior to the XAS measurements, the as-synthesized sample was kept in air. The representative Mn K-edge XAS data in the energy range from 6339 to $7339 \mathrm{eV}$ is shown in Fig. 2(a). There was a small jump above the edge at $\sim 7100 \mathrm{eV}$, which implied the presence of Fe impurity. Further Fe K-edge XANES data showed that its curve is similar to that of $\mathrm{Fe}_{2} \mathrm{O}_{3}$ (Fig. 2(b)). This finding revealed the existence of impurity $\mathrm{Fe}$ in the form of $\mathrm{Fe}$ oxide. This minor amount of $\mathrm{Fe}$ oxide may be from the preparation of the CNTs. In order to exclude the interference of $\mathrm{Fe}$, we chose $7050 \mathrm{eV}$ as the upper limit of the X-ray photon energy for collecting the Mn K-edge EXAFS data.

To better understand the influence of a $\mathrm{H}_{2}$ atmosphere on the structure of the Rh-Mn NPs, the stability of these NPs in the noble gas should be examined, and small molecules adsorbed on their surfaces such as $\mathrm{H}_{2} \mathrm{O}$ molecules should be removed. So we also performed XAS measurements for the Rh-Mn@CNT sample in He at different temperatures. The Mn K-edge XANES spectra of the Rh-Mn@CNT catalyst in a He atmosphere at different temperatures are shown in Fig. 3(a). The appearance of a pre-edge peak at $6540.7 \mathrm{eV}$ indicated that most Mn species existed in the form of Mn oxides [35]. Significantly, these XANES spectra have a broad main edge crest, which suggested the existence of different kinds of $\mathrm{Mn}$ oxide phases $\left(\mathrm{MnO}_{x}\right)$.
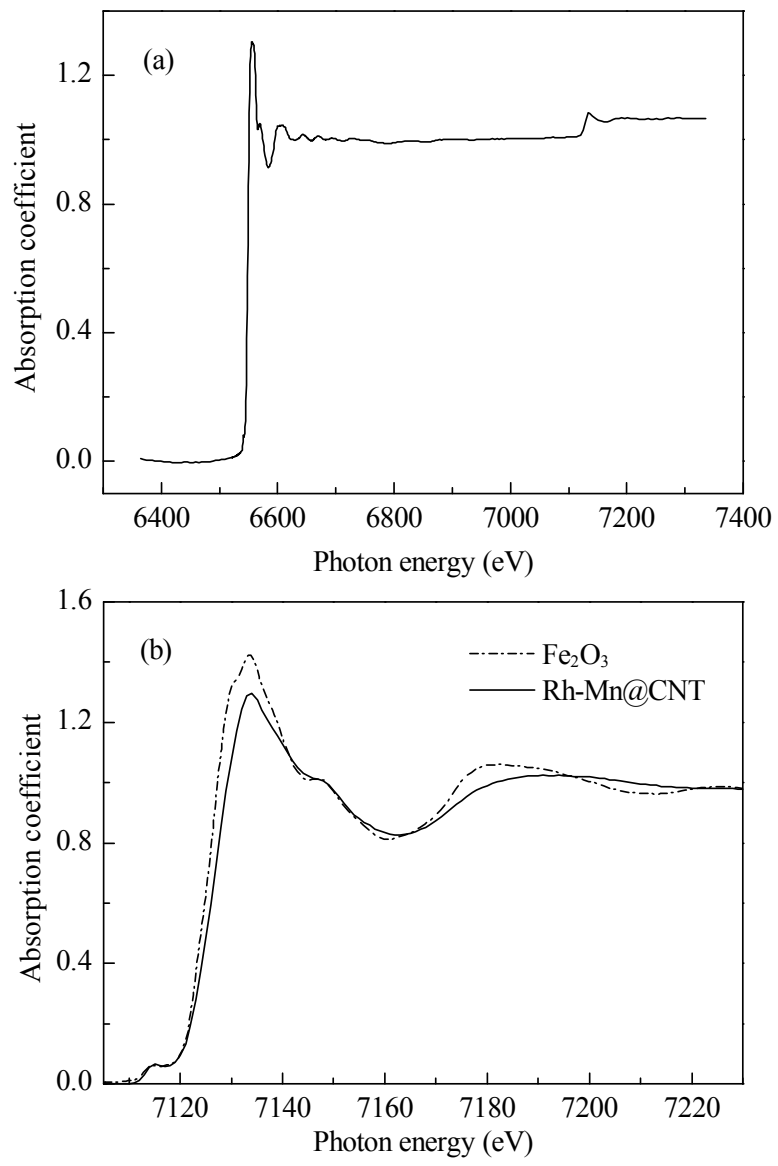

Fig. 2. (a) Mn K-edge XAS spectra of Rh-Mn@CNT; (b) Fe K-edge XANES spectra for Rh-Mn@CNT and the reference of $\mathrm{Fe}_{2} \mathrm{O}_{3}$.
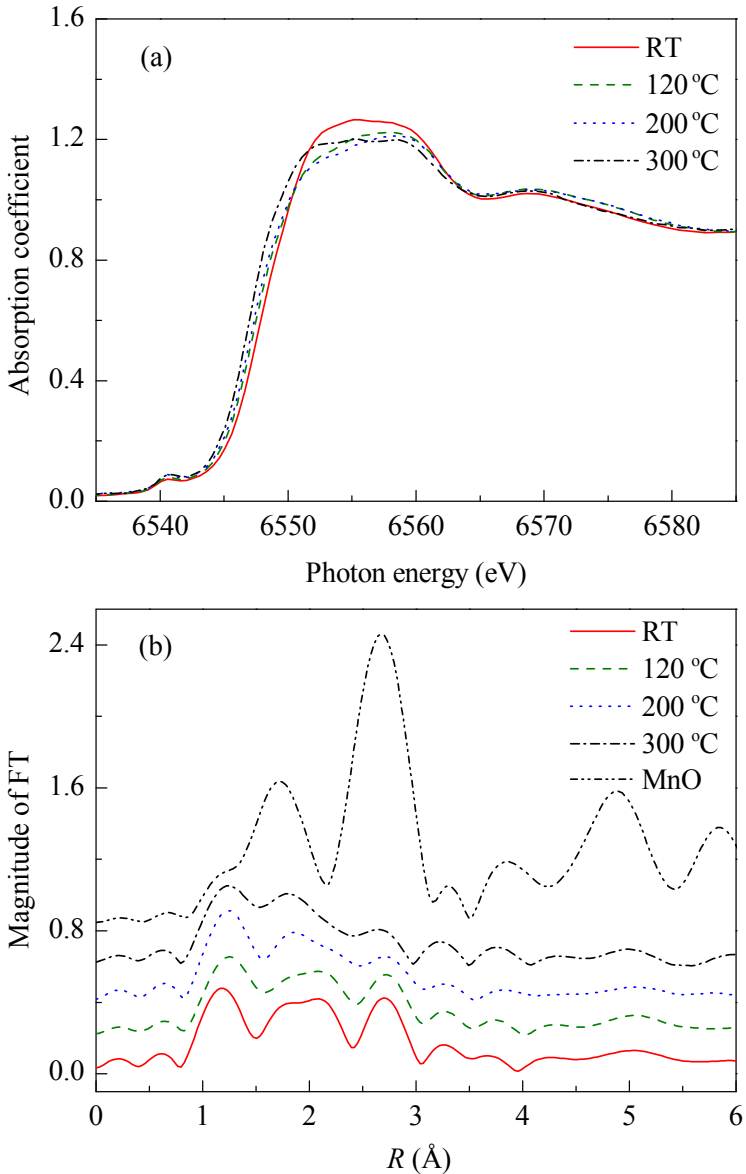

Fig. 3. (a) Mn K-edge XANES spectra for Rh-Mn@CNT in a He atmosphere at different temperatures; (b) Comparison of the FT of the Mn K-edge EXAFS spectra with that of MnO.

There was an obvious difference between the spectrum collected at RT and that at $120^{\circ} \mathrm{C}$, which can be attributed to the removal of adsorbed $\mathrm{H}_{2} \mathrm{O}$ molecules. Moreover, these broad main edge crests showed a similar shape, which proved that the mixed Mn oxide phases were stable under the He atmosphere. With increasing temperature, the edge position showed a minor shift to low energy, which can be attributed to the partial reduction of the Mn oxides. The Fourier transform (FT) of the EXAFS data is shown in Fig. 3(b). The Fourier transformed EXAFS spectra of Rh-Mn@CNT have similar features, which showed that there was no apparent change in the local structure of Mn. The peak at $2.7 \AA$ can be attributed to the Mn-O-Mn contribution. Its intensity decreased with increasing temperature, indicating the increase of disorder. These FT data could not be explained by a simple structural model. The intensity of the peaks at $2.7 \AA$ was quite weak, showing that the $\mathrm{MnO}_{x}$ were amorphous.

After a thermal treatment in a He atmosphere, the sample was further treated in $10 \% \mathrm{H}_{2}-90 \%$ He atmosphere at different temperatures. The Mn K-edge XANES data are shown in Fig. 4(a). With the temperature increase, the broad main edge crest became narrower and the edge position showed a small shift to low energy. These results implied some reduction and that the mixed $\mathrm{MnO}_{x}$ phases were changed to a pure phase. In addition, 

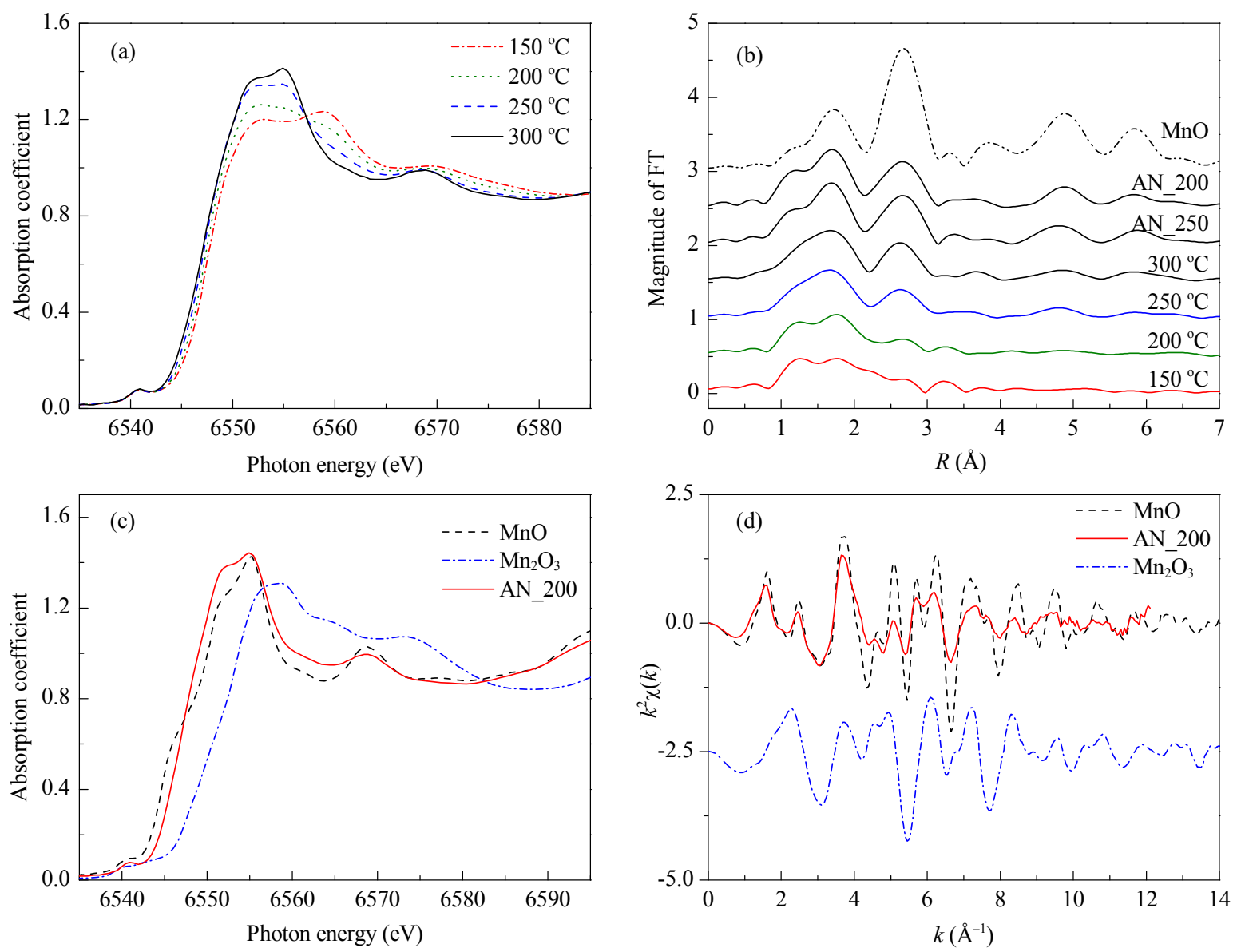

Fig. 4. (a) Mn K-edge XANES spectra for Rh-Mn@CNT in an atmosphere of $10 \% \mathrm{H}_{2}-90 \%$ He at different temperatures; (b) Comparison of the FT Mn K-edge EXAFS spectra with those of MnO and Rh-Mn@CNT under an annealing treatment at $250{ }^{\circ} \mathrm{C}$ (AN_250) and 200 ${ }^{\circ} \mathrm{C}$ (AN_200); (c) Mn K-edge XANES and (d) the corresponding $k^{2}$-weighted $\chi(k)$ data for $\mathrm{MnO}, \mathrm{Mn}_{2} \mathrm{O}_{3}$, and AN_200.

the intensity of the peak at $6569 \mathrm{eV}$ also increased with temperature, indicating more ordered structure in the medium and long range environment. It should be noted that the pre-edge peak at $6540.7 \mathrm{eV}$ was independent of the temperature, which agreed with that the pre-edge feature of the Mn oxides was much less affected by changes in the medium and long range environment than the edge region. The Fourier transformed Mn K-edge EXAFS data of the sample in $10 \% \mathrm{H}_{2}-90 \% \mathrm{He}$ atmosphere at different temperatures are shown in Fig. 4(b). The peaks at 1.7 and $2.7 \AA$ are the $\mathrm{Mn}-\mathrm{O}$ and $\mathrm{Mn}-\mathrm{O}-\mathrm{Mn}$ contributions, respectively. At temperatures below $250^{\circ} \mathrm{C}$, the EXAFS spectra were similar to those in a He atmosphere. It is significant that when the temperature was above $250{ }^{\circ} \mathrm{C}$, the EXAFS spectra were similar in character to that of $\mathrm{MnO}$, which has peaks at 1.7, 2.7, 4.8, and $5.8 \AA$. . This phenomenon is more obvious for the sample annealed at 200 and $250{ }^{\circ} \mathrm{C}$ (pattern AN_200 and AN_250), which suggested that most Mn atoms in reduced Rh-Mn@CNT were in the MnO form. Although it is difficult to determine the redox state of Mn by only using the Mn K-edge position [35], there is an approximate linear correlation between the K-edge position and the redox state of simple $\mathrm{Mn}$ oxides, such as $\mathrm{MnO}, \mathrm{Mn}_{3} \mathrm{O}_{4}, \mathrm{Mn}_{2} \mathrm{O}_{3}$, and $\beta-\mathrm{MnO}_{2}[36,37]$. It is possible to determine the oxidation state of closely related compounds by the comparison with the standard samples [38]. The comparison of the Rh-Mn@CNT sample annealed at $200{ }^{\circ} \mathrm{C}$
(AN_200) with the $\mathrm{MnO}$ and $\mathrm{Mn}_{2} \mathrm{O}_{3}$ samples is shown in Fig. 4(c). The Mn K-edge position and shape of AN_200 were close to that of $\mathrm{MnO}$, impling that most $\mathrm{Mn}$ species in reduced Rh-Mn@CNT were $\mathrm{Mn}^{2+}$. In addition, the EXAFS oscillation of the AN_200 sample has a similar frequency but with lower amplitude in comparison with that of MnO (Fig. 4(d)). The lower oscillation amplitude was due to the small size of the Rh-Mn NPs and the increase in disorder at higher temperature. The above results and analysis demonstrated that the chemical state of the promoter Mn was close to +2 for the Rh-Mn@CNT catalyst under the $10 \% \mathrm{H}_{2}-90 \% \mathrm{He}$ atmosphere at $300{ }^{\circ} \mathrm{C}$. This result is consistent with the widely accepted view that $\mathrm{MnO}$ is difficult to reduce to metallic Mn even when placed in contact with $\mathrm{Rh}[30,39]$. Moreover, in the $\mathrm{H}_{2}$-TPR result reported by $\mathrm{Li}$ et al. [24], the $\mathrm{Mn} / \mathrm{CNT}$ catalysts with $\mathrm{MnO}_{x}$ particles between 10 and $40 \mathrm{~nm}$ showed two redox peaks at 290 and $410{ }^{\circ} \mathrm{C}$ from the reduction of $\mathrm{MnO}_{2}$ or $\mathrm{Mn}_{2} \mathrm{O}_{3}$ to $\mathrm{Mn}_{3} \mathrm{O}_{4}$, and $\mathrm{Mn}_{3} \mathrm{O}_{4}$ to $\mathrm{MnO}$, respectively. For our $\mathrm{Rh}-\mathrm{Mn}$ particles, the lower reduction temperature may arise from the smaller $\mathrm{MnO}_{x}$ particles. In the EXAFS spectra, there was no peak from reduced Rh-Mn@CNT that could be attributed to $\mathrm{Mn}-\mathrm{O}-\mathrm{Rh}$ and $\mathrm{Mn}-\mathrm{Rh}$ contributions, indicating that there was no significant interaction between $\mathrm{Mn}$ and $\mathrm{Rh}$. We concluded that the mixed $\mathrm{MnO}_{x}$ phases can be reduced to $\mathrm{MnO}$ species by $\mathrm{H}_{2}$ at temperatures above $250^{\circ} \mathrm{C}$.

In addition, Rh K-edge XAS data of the Rh-Mn@CNT catalyst 

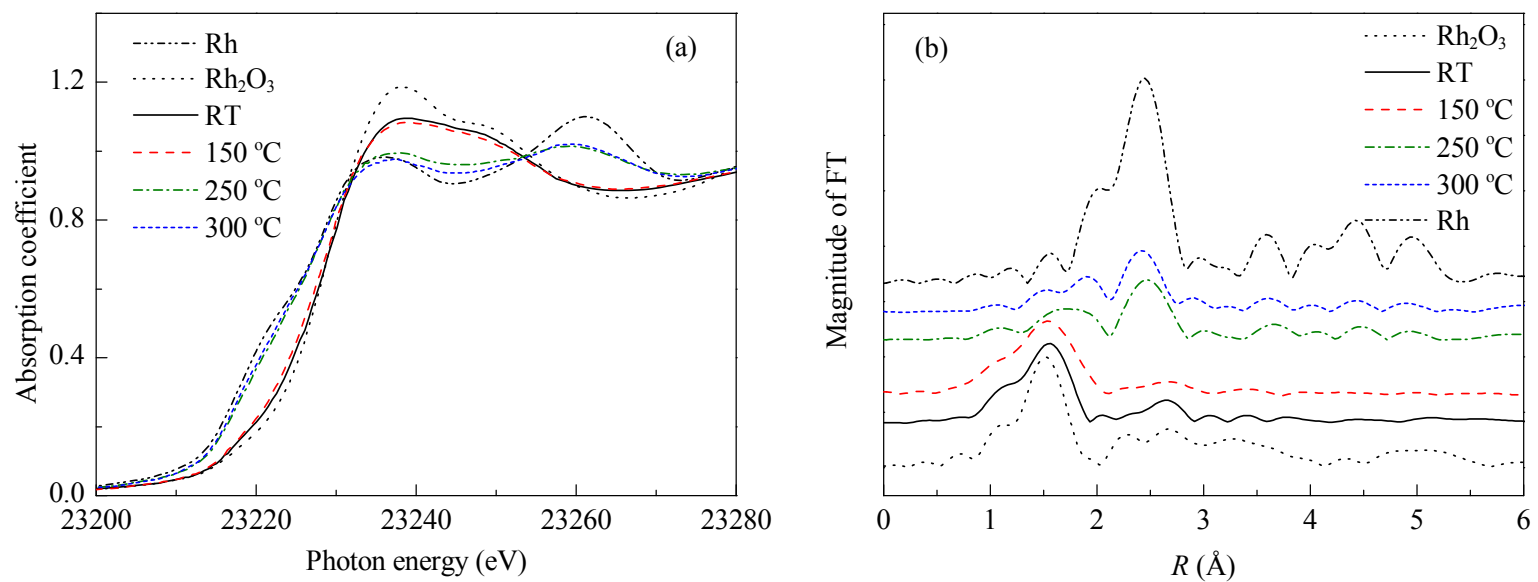

Fig. 5. (a) Rh K-edge XANES spectra for Rh-Mn@CNT in a He atmosphere at different temperatures and the references of $\mathrm{Rh}_{\text {foil }}$ and $\mathrm{Rh} \mathrm{O}_{3}$; (b) FT Rh K-edge EXAFS spectra.

under different atmospheres and temperatures were also collected. The XANES spectra for Rh-Mn@CNT in a He atmosphere at different temperatures are shown in Fig. 5(a). The first absorption peak centered at $23240 \mathrm{eV}$ in the main edge region is from the transition of electrons from the $1 s$ states to unoccupied $p$ orbitals [40]. Therefore, any variation in the oxidation state will be reflected in the intensity of the first absorption peak. Figure 5(a) shows that the initial Rh-Mn@CNT sample at RT has an obvious peak at $23240 \mathrm{eV}$, indicating the oxidation state of Rh. The Rh K-edge position of the sample both at RT and $150{ }^{\circ} \mathrm{C}$ was close to that of $\mathrm{Rh}_{2} \mathrm{O}_{3}$, further revealing the presence of $\mathrm{RhO}_{x}$. The edge position shifted to be close to that of $\mathrm{Rh}$ foil when the temperature reached $250^{\circ} \mathrm{C}$, revealing the formation of metallic Rh. The first peak $(23236 \mathrm{eV})$ above the edge for the Rh-Mn@CNT sample at $300{ }^{\circ} \mathrm{C}$ was very similar to that of $\mathrm{Rh}$ foil, indicating that there was no significant electronic effect induced by the presence of $\mathrm{Mn}$, which was similar to the result of Schwartz et al. [28]. This result was further confirmed by later EXAFS analysis. Moreover, the sample at $300{ }^{\circ} \mathrm{C}$ has a smaller peak at $23260 \mathrm{eV}$ in comparison to the $\mathrm{Rh}$ foil as a result of the small size of the metallic $\mathrm{Rh}$ particles. This result showed that the oxidized Rh particles were not stable and can be decomposed to metallic $\mathrm{Rh}$ particles in $\mathrm{He}$ when the temperature reached $250{ }^{\circ} \mathrm{C}$. A similar result was observed by $\mathrm{H}_{2}$-TPR data, that is, $\mathrm{Rh}_{2} \mathrm{O}_{3}$ is not very stable and can be reduced by $\mathrm{H}_{2}$ at a relatively low temperature (about $150{ }^{\circ} \mathrm{C}$ ) $[41,42]$. The formation of metallic Rh particles was further confirmed by the formation of $\mathrm{Rh}-\mathrm{Rh}$ coordination at $2.5 \AA$ accompanying with much decreased Rh-0 coordination at $1.5 \AA$ (Fig. 5(b)). This result further demonstrated that Rh oxide was converted to metallic $\mathrm{Rh}$ and clearly indicated that the $\mathrm{Rh}-\mathrm{O}$ interaction was relatively weak and can be decomposed in a $\mathrm{He}$ atmosphere above $250{ }^{\circ} \mathrm{C}$. There was no observable peak that can be attributed to a Rh-Mn contribution, which indicated the absence of a Rh-Mn bimetallic alloy. We concluded that $\mathrm{RhO}_{x}$ will be decomposed to metallic Rh under He when the temperature is above $250{ }^{\circ} \mathrm{C}$.

After the thermal treatment in a He atmosphere, the sample was further reduced in a $10 \% \mathrm{H}_{2}-90 \% \mathrm{He}$ atmosphere followed by a thermal treatment in a $10 \% \mathrm{CO}-90 \%$ He atmosphere. The Rh K-edge XANES spectra of the sample under the different reduction atmospheres from 150 to $300{ }^{\circ} \mathrm{C}$ have the same shape (Fig. 6). The result showed that the local electronic structure of $\mathrm{Rh}$ has no significant change and $\mathrm{Rh}$ was maintained in the metal state. In contrast, the corresponding FT of the EXAFS spectra showed some dependence on the temperature (Fig. 7). The second peak at $2.5 \AA$ was attributed to the $\mathrm{Rh}-\mathrm{Rh}$ contribution. Figure 7 (a) shows that the second peak gradually decreased with temperature from RT to $300{ }^{\circ} \mathrm{C}$, which indicated the increase of both the disorder and dispersion of Rh particles at higher temperature. In the case of the $10 \%$ CO-90\% He atmosphere (Fig. 7(b)), the second peak showed a similar trend but without a regular pattern as compared to that in Fig. 7(a). These results revealed an obvious improvement in the dispersion of the Rh particles in the Rh-Mn NPs at $300{ }^{\circ} \mathrm{C}$ under the reduction atmosphere.

The structural parameters from fitting the Mn K-edge and Rh K-edge EXAFS data are given in Table 1. The results showed that the bond lengths of $\mathrm{Mn}-\mathrm{O}$ and $\mathrm{Mn}-\mathrm{O}-\mathrm{Mn}$ in the Rh-Mn@CNT catalyst after reduction (AN_200) were close to

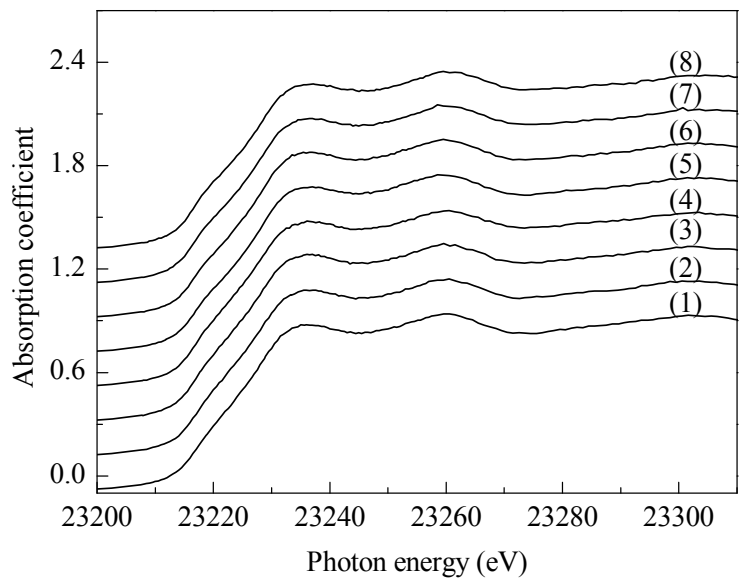

Fig. 6. Comparison of Rh K-edge XANES data for Rh-Mn@CNT in 10\% $\mathrm{H}_{2}-90 \% \mathrm{He}((1)-(4))$ with $10 \% \mathrm{CO}-90 \% \mathrm{He}((5)-(8))$ at $150((1)$ and (5)), 200 ((2) and (6)), 250 ((3) and (7)), and $300^{\circ} \mathrm{C}((4)$ and (8)). 

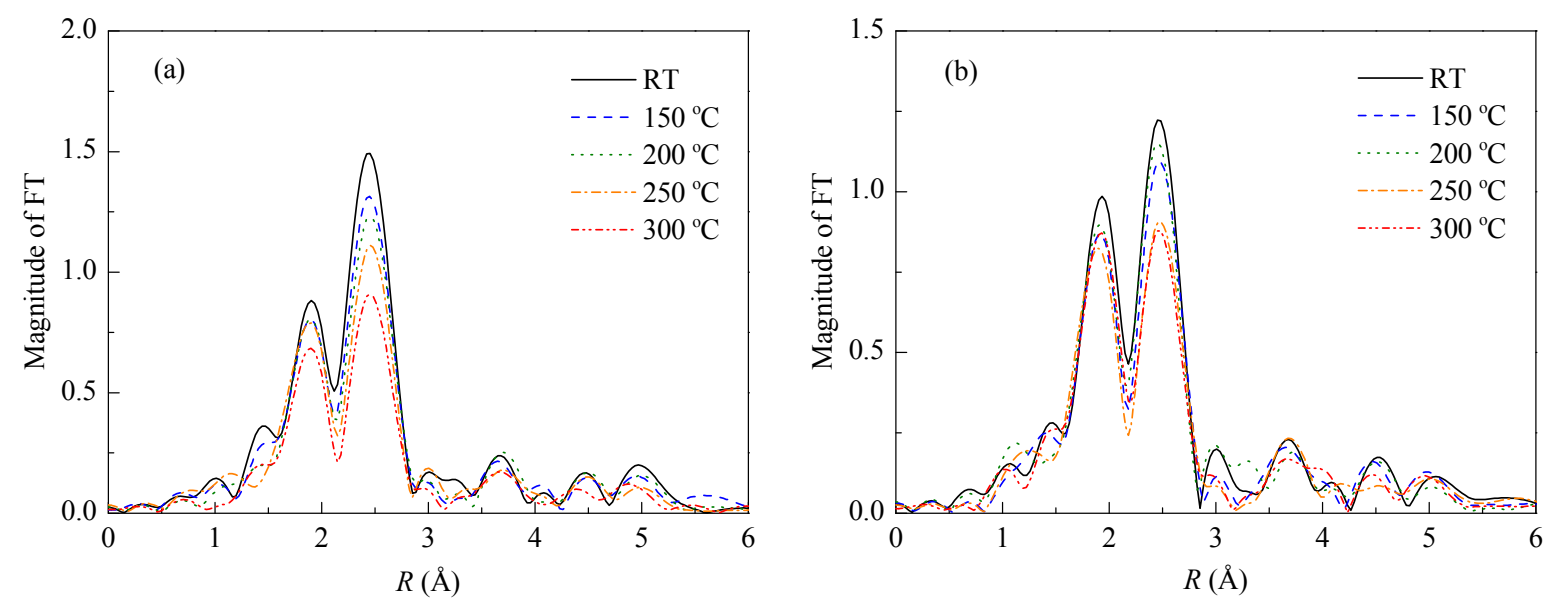

Fig. 7. (a) FT Rh K-edge EXAFS data in $10 \% \mathrm{H}_{2}-90 \% \mathrm{He}$ and (b) in $10 \% \mathrm{CO}-90 \%$ He at different temperatures.

those of MnO. In addition, the coordination number $(N)$ of the $\mathrm{Mn}-\mathrm{O}$ was $5.3 \pm 0.5$, which was close to that of bulk $\mathrm{MnO}$, indicating that most $\mathrm{Mn}$ atoms were coordinated with 0 . In contrast, the $N$ of the Mn-O-Mn shell was $8.5 \pm 1.5$, which was much lower than that of $\mathrm{MnO}$ whose $\mathrm{N}$ of the $\mathrm{Mn}-\mathrm{O}-\mathrm{Mn}$ shell is 12. This result indicated that the MnO particles in reduced Rh-Mn@CNT have a very small size. Similarly, the Rh-Mn@CNT catalyst before reduction (RT_He) has similar bond length of both $\mathrm{Rh}-\mathrm{O}$ and $\mathrm{Rh}-\mathrm{O}-\mathrm{Rh}$ in comparison with $\mathrm{Rh}_{2} \mathrm{O}_{3}$. The low $N$ of the $\mathrm{Rh}-\mathrm{O}-\mathrm{Rh}$ shell suggested that the $\mathrm{Rh}$ atoms existed in the form of $\mathrm{Rh}_{2} \mathrm{O}_{3}$ clusters. For the Rh-Mn@CNT catalyst after reduction (RT_H H $_{2}$, the $N$ obtained for the Rh-Rh shell was $5.3 \pm$ 0.8 , which is much smaller than that of Rh foil. This result is an indication of highly dispersed metallic $\mathrm{Rh}$ in the catalyst. The average size of these Rh particles was estimated to be less than $1 \mathrm{~nm}$ from Rh cluster models with varying numbers of atoms $[43,44]$. In addition, no significant Rh-Mn or Rh-O-Mn interaction was observed. Together with the above TEM result, we can also estimate that the average size of the $\mathrm{MnO}$ particles was between 1 and $2 \mathrm{~nm}$.

In summary, there was no significant $\mathrm{Mn}-\mathrm{Rh}$ or $\mathrm{Mn}-\mathrm{O}-\mathrm{Rh}$ bonding from the XAS analysis, which suggested that there is no significant chemical interaction between the $\mathrm{MnO}$ particles and the Rh clusters even though they were in physical contact. Moreover, when Rh-Mn@CNT was placed under a 10\% $\mathrm{H}_{2}-90 \%$ He atmosphere from 250 to $300{ }^{\circ} \mathrm{C}$, the size of the $\mathrm{MnO}$ parti-

Table 1

Structural parameters from the EXAFS spectra at the Mn K-edge and Rh K-edge for Rh-Mn@CNT.

\begin{tabular}{lccccc}
\hline Sample a & Path & $N$ & $R(\AA)$ & $\sigma^{2}\left(10^{-3} \AA^{2}\right)$ & $\Delta E_{0}(\mathrm{eV})$ \\
\hline RT_He & Rh-O & $4.6 \pm 0.4$ & $2.06 \pm 0.01$ & $2.4 \pm 0.9$ & $0.8 \pm 0.9$ \\
& Rh-O-Rh & $1.4 \pm 0.6$ & $2.76 \pm 0.02$ & $5.8 \pm 2.8$ & $9.1 \pm 2.6$ \\
RT_H2 & Rh-O & $1.1 \pm 0.4$ & 2.06 b & 6.0 b & 2.3 \\
& Rh-Rh & $5.3 \pm 0.8$ & $2.67 \pm 0.01$ & $4.2 \pm 0.9$ & $-9.5 \pm 1.1$ \\
AN_200 & Mn-O & $5.3 \pm 0.5$ & $2.19 \pm 0.01$ & $10.3 \pm 1.4$ & 3.4 \\
& Mn-O-Mn & $8.5 \pm 1.5$ & $3.15 \pm 0.01$ & $17.1 \pm 1.9$ & -1.7 \\
\hline
\end{tabular}

a RT_He, RT_H2, and AN_200 represent the Rh-Mn@CNT samples in He atmosphere at RT, in $10 \% \mathrm{H}_{2}-90 \%$ He atmosphere at RT, and in $10 \%$ $\mathrm{H}_{2}-90 \%$ He atmosphere under annealing treatment at $200{ }^{\circ} \mathrm{C}$, respectively.

${ }^{\mathrm{b}}$ This value is set to get a better fitting. cles showed a significant increase, and the size of the Rh clusters showed an obvious decrease. This is indicative of the promotion for the dispersion of metallic Rh clusters by the MnO particles. Accordingly, the promoter Mn improved the Rh dispersion.

\section{Conclusions}

The structure of Rh-Mn NPs confined in MWCNTs (Rh-Mn@CNT) was studied by XANES and EXAFS. The Rh-Mn nanoparticles were distributed in CNT channels with a uniform size of $2 \mathrm{~nm}$. Before reduction, the $\mathrm{Mn}$ and $\mathrm{Rh}$ species existed in the form of $\mathrm{MnO}_{x}$ and $\mathrm{Rh}_{2} \mathrm{O}_{3}$ clusters, respectively. Under a reduction atmosphere, the $\mathrm{MnO}_{x}$ species were reduced to $\mathrm{MnO}$ as a stable oxide, and the $\mathrm{Rh}_{2} \mathrm{O}_{3}$ clusters were not stable and were decomposed to Rh clusters even under a He atmosphere at 250 ${ }^{\circ} \mathrm{C}$. The Rh clusters were stable and remained in the metallic $\mathrm{Rh}$ state in an atmosphere of $10 \% \mathrm{H}_{2}$ or $10 \% \mathrm{CO}$ balanced with He. No interaction between Rh and Mn in reduced Rh-Mn@CNT was observed.

\section{Acknowledgments}

We thank the research group of Nano and Interface Catalysis at the State Key Laboratory of Catalysis at Dalian Institute of Chemical Physics, Chinese Academy of Sciences for supplying the Rh-Mn@CNT sample, and also thank Mr. Renduo Liu at the Shanghai Institute of Applied Physics, Chinese Academy of Sciences for TEM measurement and the members of the Beam Line BL14W1 at SSRF for XAS beam time.

\section{References}

[1] Rostrup-Nielsen J R. Science, 2005, 308: 1421

[2] Farrell A E, Plevin R J, Turner B T, Jones A D, O'Hare M, Kammen D M. Science, 2006, 311: 506

[3] Surisetty V R, Dalai A K, Kozinski J. Appl Catal A, 2011, 404: 1

[4] Xiao K, Bao Z H, Qi X Z, Wang X X, Zhong L S, Fang K G, Lin M G, Sun Y H. Chin J Catal (肖康, 鲍正洪, 齐行振, 王新星, 钟良枢, 房克功, 林明桂, 孙予罕. 催化学报), 2013, 34: 116

[5] Spivey J J, Egbebi A. Chem Soc Rev, 2007, 36: 1514 


\title{
Graphical Abstract
}

Chin. J. Catal., 2014, 35: 1418-1427 doi: 10.1016/S1872-2067(14)60081-4

Structural changes of Rh-Mn nanoparticles inside carbon nanotubes studied by $X$-ray absorption spectroscopy

Hongliang Bao, Xueping Sun, Zheng Jiang,

Yuying Huang* , Jianqiang Wang*

Shanghai Institute of Applied Physics,

Chinese Academy of Sciences

Rh-Mn nanoparticles in reduced Rh-Mn@CNT catalyst comprise metallic $\mathrm{Rh}$ and $\mathrm{MnO}$ that do not have significant interaction.

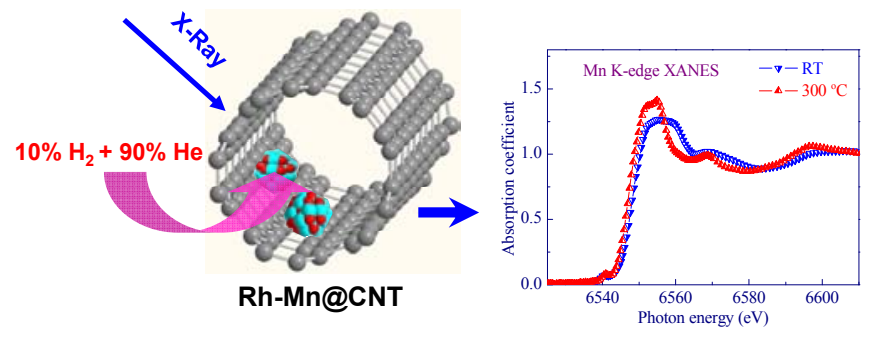

[6] Subramani V, Gangwal S K. Energy Fuels, 2008, 22: 814

[7] Burch R, Petch M I. Appl Catal A, 1992, 88: 77

[8] Burch R, Petch M I. Appl Catal A, 1992, 88: 39

[9] Lisitsyn A S, Stevenson S A, Knözinger H.J Mol Catal, 1990, 63: 201

[10] Burch R, Hayes M J. J Catal, 1997, 165: 249

[11] Gao J, Mo X, Goodwin J G Jr. J Catal, 2009, 268: 142

[12] Haider M A, Gogate M R, Davis R J. J Catal, 2009, 261: 9

[13] Ehwald H, Ewald H, Gutschick D, Hermann M, Miessner $\mathrm{H}_{4}$ Ohlmann G, Schierhorn E. Appl Catal, 1991, 76: 153

[14] Gao J, Mo X H, Chien A C Y, Torres W, Goodwin J G Jr. J Catal, 2009, 262: 119

[15] Li C M, Liu J M, Gao W, Zhao Y F, Wei M. Catal Lett, 2013, 143: 1247

[16] Jiang D H, Ding Y J, Lü Y, Zhu H J, Chen W M, Wang T, Yan L, Luo H Y. Chin J Catal (江大好, 丁云杰, 吕元, 朱何俊, 陈维苗, 王涛, 严 丽, 罗洪原. 催化学报), 2009, 30: 697

[17] Li J W, Ding Y J, Lin R H, Gong L F, Song X G, Chen W M, Wang T, Luo H Y. Chin J Catal (李经伟, 丁云杰, 林荣和, 龚砧峰, 宋宪根, 陈维苗, 王涛, 罗洪原. 催化学报), 2010, 31: 365

[18] Yin H M, Ding Y J, Luo H Y, Xiong J M, He D P, Wang T, Lin L W. Chin J Catal (尹红梅, 丁云杰, 罗洪原, 熊建民, 何代平, 王涛, 林励吾. 催化学报), 2002, 23: 352

[19] Pan X L, Fan Z L, Chen W, Ding Y J, Luo H Y, Bao X H. Nat Mater, 2007, 6: 507

[20] Pan X L, Bao X H. Acc Chem Res, 2011, 44: 553

[21] Song X G, Ding Y J, Chen W M, Dong W D, Pei Y P, Zang J, Yan L, Lü Y. Catal Commun, 2012, 19: 100

[22] Chen G C, Guo C Y, Zhang X H, Huang Z J, Yuan G Q. Fuel Process Technol, 2011, 92: 456

[23] Zhang H B, Pan X L, Bao X H. J Energy Chem, 2013, 22: 251

[24] Li L, Wang L S, Pan S W, Wei Z L, Huang B C. Chin J Catal (李丽, 王 丽珊，盘思伟，韦正乐，黄碧纯. 催化学报), 2013, 34: 1087

[25] Zhang H B, Pan X L, Liu J Y, Qian W Z, Wei F, Huang Y Y, Bao X H.
ChemSusChem, 2011, 4: 975

[26] Ojeda M, Granados M L, Rojas S, Terreros P, Garcia-Garcia F J, Fierro J L G. Appl Catal A, 2004, 261: 47

[27] Mei D H, Rousseau R, Kathmann S M, Glezakou V A, Engelhard M H, Jiang W L, Wang C H, Gerber M A, White J F, Stevens D J. J Catal, 2010, 271: 325

[28] Schwartz V, Campos A, Egbebi A, Spivey J J, Overbury S H. ACS Catal, 2011, 1: 1298

[29] Wilson T P, Kasai P H, Ellgen P C. J Catal, 1981, 69: 193

[30] De Jong K P, Glezer J H E, Kuipers HPCE, Knoester A, Emeis C A. J Catal, 1990, 124: 520

[31] Luo H Y, Lin P Z, Xie S B, Zhou H W, Xu C H, Huang S Y, Lin L W, Liang D B, Ying P L, Xin Q.J Mol Catal A, 1997, 122: 115

[32] Rehr J J, Albers R C. Rev Mod Phys, 2000, 72: 621

[33] Singh J, Lamberti C, van Bokhoven J A. Chem Soc Rev, 2010, 39: 4754

[34] Newville M.J Synchrotron Radiat, 2001, 8: 322

[35] Farges F. Phys Rev B, 2005, 71: 155109

[36] Campos A, Lohitharn N, Roy A, Lotero E, Goodwin J G Jr, Spivey J J. Appl Catal A, 2010, 375: 12

[37] Figueroa S J A, Requejo F G, Lede E J, Lamaita L, Peluso M A, Sambeth J E. Catal Today, 2005, 107-108: 849

[38] McKeown D A, Kot W K, Gan H, Pegg I L. J Non-Cryst Solids, 2003, 328: 71

[39] Trevino H, Lei G D, Sachtler W M H.J Catal, 1995, 154: 245

[40] Fernandez-Garcia M, Martinez-Arias A, Rodriguez-Ramos I, Ferreira-Aparicio P, Guerrero-Ruiz A. Langmuir, 1999, 15: 5295

[41] Yu J, Mao D S, Han L P, Guo Q S, Lu G Z. Fuel Process Technol, 2013, 106: 344

[42] Han L P, Mao D S, Yu J, Guo Q S, Lu G Z. Appl Catal A, 2013, 454: 81

[43] Frenkel A I, Hills C W, Nuzzo R G.J Phys Chem B, 2001, 105: 12689

[44] Overbury S H, Schwartz V, Mullins D R, Yan W F, Dai S. J Catal, 2006, 241: 56

\section{X射线吸收谱研究碳纳米管内 Rh-Mn纳米粒子结构的变化}

\author{
鲍洪亮，孙雪平，姜政，黄宇营"，王建强 ${ }^{*}$ \\ 中国科学院上海应用物理研究所微观界面物理与探测重点实验室和上海同步辐射光源, 上海201204
}

摘要: 利用X射线吸收谱技术研究了负载于多壁碳纳米管内的 Rh-Mn纳米粒子在不同气氛和温度下的结构. 结果表明, Rh-Mn粒 子在空气中是由氧化铑团簇和混合锰氧化物组成. 经过氢气在 $300{ }^{\circ} \mathrm{C}$ 下还原后, 混合锰氧化物种转化成 $\mathrm{MnO}$. 而氧化铑团簇在 $\mathrm{He}$ 气氛下当温度达到 $250^{\circ} \mathrm{C}$ 时就会发生分解而形成金属铑团簇. 对形成的铑团簇用 $\mathrm{H}_{2}$ 或 $\mathrm{CO}$ 进行热处理, 发现其分散性随温度升高 而提高; 同时, $\mathrm{X}$ 射线吸收谱实验没有观察到 $\mathrm{Mn}$ 和 $\mathrm{Rh}$ 之间存在显著的相互作用, 助剂 $\mathrm{Mn}$ 的主要作用是提高了 $\mathrm{Rh}$ 的分散性. 
关键词: 铑; 镍; 纳米粒子; X射线吸收近边结构; 扩展X射线吸收精细结构

收稿日期: 2014-01-20. 接受日期: 2014-03-12. 出版日期: 2014-08-20.

*通讯联系人. 电话/传真: (021)33933212; 电子信箱：wangjianqiang@sinap.ac.cn

\#通讯联系人. 电话/传真: (021)33933212; 电子信箱: huangyuying@sinap.ac.cn

基金来源：国家自然科学基金(91127001, 21001112和11079005).

本文的英文电子版由Elsevier出版社在ScienceDirect上出版(http://www.sciencedirect.com/science/journal/18722067).

\section{1. 前言}

乙醇用于燃料可以降低地球对石油的依赖, 最近几 年合成气制乙醇得到了重点关注 ${ }^{[1-4]}$. 催化转化生物质 制合成气为这一途径大规模合成乙醇提供了潜在机 会 ${ }^{[5]}$. 虽然对这一合成方法进行了大量研究, 但一直还 没有进入商业化生产 ${ }^{[6]}$. 一个共同的认识是负载型Rh粒 子可以同时以分子和解离形式吸附 $\mathrm{CO}$, 但是存在的问 题是催化性能不好 ${ }^{[7,8]}$. 为了增强 $R \mathrm{~h}$ 的催化性能, 研究人 员在选择合适的载体和添加不同助剂等方面做了大量 工作 ${ }^{[9-18]}$. 最近, 研究发现将 $\mathrm{Rh}$ 或 $\mathrm{Rh}$ 基纳米粒子限制在 某些空间内, 例如分子篮材料和碳纳米管等, 可以有效 提高合成气制乙醇的产率和选择性 ${ }^{[19-25]}$.

$\mathrm{Mn}$ 作为一种常用助剂被广泛添加到 Rh中形成 $\mathrm{Rh}-\mathrm{Mn}$ 催化剂. 许多工作研究了 $\mathrm{Mn}$ 在负载型 Rh-Mn催 化剂上的增强活性效应 ${ }^{[26-28]}$. 然而, 对 $\mathrm{Mn}$ 的化学态及 $\mathrm{Mn}$ 与 Rh之间的相互作用还不清楚. Wilson等 ${ }^{[29]}$ 发现, $\mathrm{Mn}$ 以 $\mathrm{Mn}^{2+}$ 和 $\mathrm{Rh}^{+}$共存在氧化硅载体上. 而且, 研究还发 现Rh-Mn催化剂中的Mn氧化物不能够被完全还原成金 属 $\mathrm{Mn}^{[30]}$. 相比之下, Luo等 ${ }^{[3]}$ 发现, Rh可以促进 $\mathrm{Mn}$ 氧化 物的还原. 除此之外, 研究还发现助剂 $\mathrm{Mn}$ 是以双金属合 金的形式与 $\mathrm{Rh}$ 共存的 ${ }^{[27]}$. 因此, 确定助剂 $\mathrm{Mn}$ 的化学态 和辨识 $\mathrm{Mn}$ 与 $\mathrm{Rh}$ 之间的相互作用对于认识 $\mathrm{Mn}$ 的提高效 应就显得很关键. X射线吸收谱(XAS), 包括X射线吸收 近边结构(XANES)和扩展X射线吸收精细结构(EXAFS), 是一种材料研究的有用工具, 它可以提供吸收原子的电 子结构和周围的局域几何结构 ${ }^{[32]}$. 此外, XAS技术还具 有元素分辨特性且可用于原位条件下的研究 ${ }^{[33]}$. 因此, 它很适合对反应气氛下的Rh-Mn催化剂进行研究.

我们选用 Rh-Mn负载型催化剂作为实例, 利用XAS 方法系统地研究了 Rh-Mn粒子的结构; 这里的Rh-Mn粒 子中的 $\mathrm{Rh}$ 和 $\mathrm{Mn}$ 在催化剂中的质量分数均为 $5 \%$. 粒子负 载在多壁碳纳米管内, 标记为Rh-Mn@CNT. 我们利用 $\mathrm{Mn}$ 和 $\mathrm{Rh}$ 的K边XAS数据研究了它们在不同化学气氛下 的化学态及其相互作用. 实验结果为理解反应条件下的 $\mathrm{Rh}-\mathrm{Mn}$ 粒子结构和Mn的增强效应提供了互补信息.

\section{2. 实验部分}

\section{1. 催化剂制备}

催化剂样品通过湿化学方法制得, 文献 ${ }^{[19]}$ 中有详细 描述. 所用多壁碳纳米管的长度为 $250-500 \mathrm{~nm}$, 内径为 4-8 $\mathrm{nm}$.

\subsection{TEM表征}

Rh-Mn@CNT的透射电镜(TEM)照片通过FEI Tecnai G2 F20 S-TWIN透射电镜获得, 使用的加速电压是 $200 \mathrm{kV}$. TEM样品的制备是将待测样品分散在乙醇中, 然后滴在铜网上在空气中自然干燥.

\subsection{XAS实验测量和数据处理}

XAS数据是在上海光源BL14W1线站上采集的. 电 子储存环的运行能量为 $3.5 \mathrm{GeV}$. 单色器使用 $\mathrm{Si}(111)$ 或 $\mathrm{Si}(311)$ 两套晶体. Mn K边XAS数据利用透射模式采集, $\mathrm{Rh} \mathrm{K}$ 边XAS数据利用荧光模式采集 (32元Ge固体探测 器). 为了进行比较, 还测量了 $\mathrm{Rh}$ 㵄、 $\mathrm{Rh}_{2} \mathrm{O}_{3} 、 \mathrm{Mn}$ 淢、 $\mathrm{MnO}$ 和 $\mathrm{Mn}_{2} \mathrm{O}_{3}$ 标样的XAS. 原位反应池用于获得样品在常压 不同温度下的XAS数据. 原位池是在商业Linkam T95装 置(购于Linkam Scientific Instruments Ltd)的基础上进行 改进而来. 化学气氛处理的顺序是先充 $\mathrm{He}$ 气, 后充 $10 \%$ $\mathrm{H}_{2}-90 \% \mathrm{He}$, 最后充 $10 \% \mathrm{CO}-90 \% \mathrm{He}$. 对于一种气体, 升 温顺序是从室温到 $300{ }^{\circ} \mathrm{C}$, 然后退火到室温. 升温速率 是 $5^{\circ} \mathrm{C} / \mathrm{min}$, 到了目标温度点, 采谱之前需保温 $1 \mathrm{~h}$. XAS 数据利用Ifeffit软件包处理 ${ }^{[34]}$. 数据处理使用 $k^{2}$ 加权, 用 $\operatorname{FEFF}\left(6.0\right.$ 版本)计算散射振幅和相移 ${ }^{[32]}$. 由拟合 $\mathrm{MnO}$ 和 $\mathrm{Rh}$ 簿标样得到的振幅衰减因子 $\left(S_{0}{ }^{2}\right)$ 分别为 0.65 和 0.85 . 通过分析可以计算得到结构参数, 例如配位数 $(N)$ 、键长 $(R)$ 、Debye-Waller因子 $\left(\sigma^{2}\right)$ 和内势能移动 $\left(\Delta E_{0}\right)$.

\section{3. 结果与讨论}

样品的详细TEM表征详见文献[19]. 这里, TEM仅 用来确认 Rh-Mn 纳米粒子负载在碳纳米管内壁. Rh-Mn@CNT催化剂的TEM照片见图1, Rh-Mn颗粒以约 $2 \mathrm{~nm}$ 的粒径分散在碳纳米管道内. 实际催化反应一般发生在特定的温度和气氛下. 为 
了研究 $\mathrm{Mn}$ 和 $\mathrm{Rh}$ 的真实化学态和局域几何结构, 我们对 其进行了不同气氛和不同温度下的原位XAS表征. XAS 测量前, 样品放置在空气中不作其它任何处理. 样品的 典型 Mn K边XAS数据见图2(a). 需要注意的是在 7100 $\mathrm{eV}$ 能量附近存在一个小跳跃, 暗示着存在 $\mathrm{Fe}$ 杂质. 进一 步的Fe K边XANES数据显示其谱形与 $\mathrm{Fe}_{2} \mathrm{O}_{3}$ 存在相似, 揭示了 $\mathrm{Fe}$ 杂质是以氧化物形式存在. 这些微量的 $\mathrm{Fe}$ 杂质 可能来源于碳纳米管的制备过程. 为了排除 $\mathrm{Fe}$ 元素的信 号干扰, 我们选择 $7050 \mathrm{eV}$ 作为 Mn K边EXAFS采集的能 量上限.

为了更好地理解 $\mathrm{H}_{2}$ 气氛对 $\mathrm{Rh}-\mathrm{Mn}$ 纳米粒子结构的 影响, 需要检查颗粒在惰性气体中的稳定性, 也需要去 除吸附在颗粒表面的小分子(例如水分子). 因此, 我们 进行了 $\mathrm{He}$ 气氛下的XAS测量, 不同温度下 $\mathrm{He}$ 气氛中的 Mn K边XANES谱见图3(a). 在6540.7 eV 处存在一个边 前峰, 暗示着大多数的 $\mathrm{Mn}$ 以 $\mathrm{Mn}$ 氧化物形式存在. 很有 意义的是, 这些XANES谱都存在很宽的主边区, 表明存 在混合 $\mathrm{Mn}$ 氧化物 $\left(\mathrm{MnO}_{x}\right)$. 此外, 这些不同温度下的 XANES谱都比较接近, 说明这些混合 $\mathrm{Mn}$ 氧化物在 $\mathrm{He}$ 气 氛下相对稳定. 当温度升高时, 吸收边位置向低能端有 微小的移动, 这主要归结于 $\mathrm{Mn}$ 氧化物的部分还原. 相应 的EXAFS数据的FT谱见图3(b). 这些谱表现出相似性, 表明 $\mathrm{Mn}$ 的局域结构没有发生明显变化. $2.7 \AA$ 处的峰可 以归结于 Mn-O-Mn路径的贡献. 且其峰强度很弱, 表明 $\mathrm{MnO}_{x}$ 是无序结构主导的. 这些FT谱没有明确的物理意 义, 不可能用一个简单的结构模型来描述.

在 $\mathrm{He}$ 中热处理后, 样品进一步在不同温度下的 $10 \%$ $\mathrm{H}_{2}-90 \% \mathrm{He}$ 气氛中处理. Mn K边XANES 见4(a). 随着温 度升高, 低宽的主边区边变得高瘦, 且吸收边位置向低 能端有小的移动, 表明发生了还原, 混合 $\mathrm{Mn}$ 氧化物趋近 于一纯相. 对应的Mn K边EXAFS 的FT谱见图 4(b), 在 $\sim 1.7$ 和 $2.7 \AA$ 处的峰分别归结于 $\mathrm{Mn}-\mathrm{O}$ 和 Mn-O-Mn的贡 献. 当温度达到和超过 $250^{\circ} \mathrm{C}$ 时, 样品的EXAFS谱表现 出与 $\mathrm{MnO}$ 相似的特征, 主要体现在在 $1.7,2.7,4.8$ 和 $5.8 \AA$ 附近存在有意义的峰, 表明在这些阶段大多数 $\mathrm{Mn}$ 以 $\mathrm{MnO}$ 形成存在. 尽管通过 $\mathrm{Mn} \mathrm{K}$ 边的位置很难确定 $\mathrm{Mn}$ 的 化学态 ${ }^{[35]}$, 但是 $\mathrm{Mn}$ 的K边位置与简单的 $\mathrm{Mn}$ 氧化物(例如 $\mathrm{MnO}, \mathrm{Mn}_{3} \mathrm{O}_{4}, \mathrm{Mn}_{2} \mathrm{O}_{3}$ 和 $\beta-\mathrm{MnO}_{2}$ ) 之间存在一种近似线性 的关系 ${ }^{[36,37]}$. 因此通过与标样对比, 可以确定比较接近 的 $\mathrm{Mn}$ 物种的氧化态 ${ }^{[38]} .200{ }^{\circ} \mathrm{C}$ 退化的样品、 $\mathrm{MnO}$ 及 $\mathrm{Mn}_{2} \mathrm{O}_{3}$ 的XANES 谱和相应的 $k$ 空间EXAFS 振荡见图 4 . 这些结果显示助剂 $\mathrm{Mn}$ 的化学态接近 +2 价. 这一结果与
广泛接受的观点即 $\mathrm{MnO}$ 很难被还原成金属 $\mathrm{Mn}$ 相吻 合 ${ }^{[30,39]}$. 根据EXAFS 数据, 没有发现明显的Mn-O-Rh和 $\mathrm{Mn}-\mathrm{Rh}$ 的贡献, 暗示着 $\mathrm{Mn}$ 和 $\mathrm{Rh}$ 之间不存在强相互作用.

在不同气氛和温度下的 $\mathrm{Rh} \mathrm{K}$ 边XANES数据见图 5 (a). 主边区中心在 $23240 \mathrm{eV}$ 附近的峰来源于 $1 s$ 电子到 未占据的 $p$ 轨道的跃迁 ${ }^{[40]}$. 因此, 与氧化态相关的任何 变化都会反映在这个吸收峰上. 图 5(a) 表明室温和 $150{ }^{\circ} \mathrm{C}$ 下样品的 $\mathrm{Rh} \mathrm{K}$ 边位置都接近于 $\mathrm{Rh}_{2} \mathrm{O}_{3}$ 的, 揭示其 中的 $\mathrm{Rh}$ 以 $\mathrm{RhO}_{x}$ 存在. 而当温度达到 $250{ }^{\circ} \mathrm{C}$ 时, 吸收边位 置移动到接近 $\mathrm{Rh}$ 馢位置, 说明形成了金属 $\mathrm{Rh}$. 同时, 也 说明不存在由 $\mathrm{Mn}$ 引起的显著的电子效应, 这一结果与 Schwartz等 ${ }^{[28]}$ 的结果相似. 图5(a)说明这些氧化的 $\mathrm{Rh}$ 粒 子不稳定, 当温度达到 $250{ }^{\circ} \mathrm{C}$ 时在 $\mathrm{He}$ 气氛下就会分解成 金属 $\mathrm{Rh}$ 粒子. $\mathrm{H}_{2}$-TPR结果也发现 $\mathrm{Rh}_{2} \mathrm{O}_{3}$ 不稳定, 在 $\mathrm{H}_{2}$ 气 氛中大约 $150{ }^{\circ} \mathrm{C}$ 就会被还原 ${ }^{[41,42]}$. 相应的Rh K边EXAFS 数据见图 5(b). 位于 $1.5 \AA$ 和 $2.5 \AA$ 附近的峰归属于 $\mathrm{Rh}-\mathrm{O}$ 和 Rh-Rh路径的贡献. 也未发现Rh-Mn的贡献, 暗示着没 有形成Rh-Mn双金属合金.

$\mathrm{He}$ 气处理过后, 样品紧接着按顺序在 $10 \% \mathrm{H}_{2}-90 \%$ $\mathrm{He}$ 及 $10 \% \mathrm{CO}-90 \% \mathrm{He}$ 气氛中热处理. 在这两种气氛下 的Rh K边XANES 见图6. 图中显示所有的XANES基本 上相同, 说明 $\mathrm{Rh}$ 的化学态没有变化, 均为金属 $\mathrm{Rh}$. 相比 之下, EXAFS的FT谱峰的强度与温度有关(图7), 整体趋 势是随着温度升高, Rh-Rh配位峰的强度下降, 说明 $\mathrm{Rh}$ 结构的无序度和Rh的分散性有一定程度的提高.

通过拟合 $\mathrm{Mn} \mathrm{K}$ 边和 Rh K边EXAFS数据所获得的参 数见表 1. 数据显示, Rh-Mn@CNT样品经过还原后 (AN_200)的 $\mathrm{Mn}-\mathrm{O}$ 和 $\mathrm{Mn}-\mathrm{O}-\mathrm{Mn}$ 键长与 $\mathrm{MnO}$ 标样的非常 接近, 而且, 其 $\mathrm{Mn}-\mathrm{O}$ 的配位数 $(5.3 \pm 0.5)$ 接近于 $\mathrm{MnO}$ 的, 说明 $\mathrm{AN} \_200$ 样品中的 $\mathrm{Mn}$ 大多数与 $\mathrm{O}$ 结合. 此外, 其 $\mathrm{Mn}-\mathrm{O}-\mathrm{Mn}$ 壳层的配位数 $(8.5 \pm 1.5)$ 明显低于 $\mathrm{MnO}$ 的, 暗 示 $\mathrm{MnO}$ 颗粒的尺寸非常小. 还原前的Rh-Mn@CNT样品 (RT_He) 具有与 $\mathrm{Rh}_{2} \mathrm{O}_{3}$ 相近的 $\mathrm{Rh}-\mathrm{O}$ 和 $\mathrm{Rh}-\mathrm{O}-\mathrm{Rh}$ 键长, 但 其 $\mathrm{Rh}-\mathrm{O}-\mathrm{Rh}$ 配位数 $(1.4 \pm 0.6)$ 明显小于 $\mathrm{Rh}_{2} \mathrm{O}_{3}$ 的, 说明 $\mathrm{Rt}$ _He样品中的 $\mathrm{Rh}$ 以 $\mathrm{Rh}_{2} \mathrm{O}_{3}$ 团簇形式存在. 对于还原后 的 Rh-Mn@CNT样品 $\left(\mathrm{RT}_{-} \mathrm{H}_{2}\right)$, 其 Rh-Rh 配位数 (5.3 \pm $0.8)$ 明显小于 $R h$ 箔的, 说明金属 $\mathrm{Rh}$ 在催化剂上是高分散 的. 根据 $\mathrm{Rh}$ 等的团簇模型 ${ }^{[43,44]}$, 估算得出 $\mathrm{Rh}$ 粒子的平均 尺寸小于 $1 \mathrm{~nm}$. 结合前文的 TEM结果, 也可以估测出 $\mathrm{MnO}$ 颗粒的尺寸是 $1-2 \mathrm{~nm}$.

总之, 对于还原后的Rh-Mn@CNT催化剂, 通过XAS 分析没有观察到 $\mathrm{Mn}-\mathrm{Rh}$ 和 $\mathrm{Mn}-\mathrm{O}-\mathrm{Rh}$ 的贡献, 说明 $\mathrm{MnO}$ 颗 
粒与 $\mathrm{Rh}$ 团簇之间尽管存在物理接触但是不存在强烈的 化学相互作用, 而且在温度从 $250{ }^{\circ} \mathrm{C}$ 升高到 $300{ }^{\circ} \mathrm{C}$ 过程 中, $\mathrm{MnO}$ 颗粒的尺寸发生变大的同时 $\mathrm{Rh}$ 团簇的尺寸则变 小, 暗示金属 $\mathrm{Rh}$ 团簇在 $\mathrm{MnO}$ 颗粒上的分散性提高. 因此, 可以推测出助剂 $\mathrm{Mn}$ 的存在主要是提高了 $\mathrm{Rh}$ 的分散性.

\section{4. 结论}

利用XANES和EXAFS技术研究了限域在碳纳米管 内的 Rh-Mn纳米粒子的结构. Rh-Mn粒子以约 $2 \mathrm{~nm}$ 的均 一尺寸分布在碳纳米管道内. 还原前, 样品中的 $\mathrm{Mn}$ 和 $\mathrm{Rh}$ 分别以 $\mathrm{MnO}_{x}$ 和 $\mathrm{Rh}_{2} \mathrm{O}_{3}$ 团簇形式存在于 $\mathrm{Rh}-\mathrm{Mn}$ 粒子中. 在
还原气氛下, $\mathrm{MnO}_{x}$ 被还原成稳定的 $\mathrm{MnO}$. 相比较而言, $\mathrm{Rh}_{2} \mathrm{O}_{3}$ 团簇不稳定, 在 $\mathrm{He}$ 气氛下 $250{ }^{\circ} \mathrm{C}$ 就会发生分解形 成 $\mathrm{Rh}$ 团簇. 形成的 $\mathrm{Rh}$ 团簇在还原气氛下相对比较稳定 而保持金属态. $\mathrm{Rh}$ 与 $\mathrm{Mn}$ 之间不存在明显的相互作用.

\section{致谢}

我们感谢中国科学院大连化学物理研究所催化基 础国家重点实验室纳米和界面催化课题组提供的 Rh-Mn@CNT样品, 同时也感谢中国科学院上海应用物 理研究所的刘仁多提供了 TEM 测试及上海光源 BL14W1线站职工提供了XAS束线时间. 